\title{
KETERKAITAN ANTAR SUBSISTEM AGRIBISNIS JAGUNG HIBRIDA DI KECAMATAN MAJA
}

\section{THE RELATIONSHIP BETWEEN HYBRID CORN AGRIBUSINESS SUBSYSTEMS IN MAJA DISTRICT}

\author{
Syifa Herliani*, Zumi Saidah, Trisna Insan Noor, Endah Djuwendah \\ Universitas Padjadjaran, Jl. Raya Sumedang-Bandung, Jawa Barat 45363 \\ *Email: syifa17005@mail.unpad.ac.id \\ (Diterima 29-12-2020; Disetujui 14-1-2021)
}

\begin{abstract}
ABSTRAK
Jagung merupakan salah satu tanaman yang bisa dikembangkan sebagai produk agroindustri karena daya saing komoditas jagung cukup baik dan nilai jual jagung cukup meningkatkan nilai ekonomis komoditas jagung. Kabupaten Majalengka menjadi salah satu sentra produksi jagung terbesar di Indonesia. Kecamatan Maja menjadi penghasil jagung terbanyak di Kabupaten Majalengka. Penelitian ini dilaksanakan di Desa Cihaur dan Desa Nunuk Baru, Kecamatan Maja, Kabupaten Majalengka. Dari subistem agribisnis jagung hibrida masih terdapat permasalahan yang menjadikan kelemahan dan ancaman pada subsistem agribisnis jagung hibrida, namun memiliki kekuatan dan peluang untuk pengembangan agribisnis jagung hibrida. Untuk itu, perlu dilakukan studi untuk melihat keterkaitan subsistem agribisnis jagung hibrida di Kecamatan Maja. Penelitian ini menggunakan analisis deskriptif kualitatif. Berdasarkan penulusuran subsistem agribisnis jagung hibrida, kelima subsistem agribisnis belum terkait dan keberadaanya masih parsial. Untuk itu diperlukan pihak yang mengelola dari subsistem hulu hingga hilir agar antar subsistem saling terkait.
\end{abstract}

Kata kunci: jagung hibrida, subsistem agribisnis, analisis deskriptif kualitatif

\section{ABSTRACT}

Corn is one of the crops that can be developed as an agro-industrial product because the competitiveness of corn is quite good and the selling value of corn is sufficient to increase the economic value of corn. Majalengka Regency is one of the largest maize production centers in Indonesia. Maja District is the largest producer of maize in Majalengka Regency. This research was conducted in Cihaur Village and Nunuk Baru Village, Maja District, Majalengka Regency. From the hybrid corn agribusiness sub-system, there are still problems that cause weaknesses and threats to the hybrid corn agribusiness subsystem, but it has the strength and opportunity for the development of hybrid corn agribusiness. For that, it is necessary to conduct a study to see the relationship between the hybrid corn agribusiness subsystem in Maja District. This study uses a qualitative descriptive analysis. Based on the research of the hybrid corn agribusiness subsystem, the five agribusiness subsystems are not related and their existence is still partial. For that we need a party that manages from upstream to downstream subsystems so that the subsystems are interrelated.

Keywords: hybrid corn, agribusiness subsystem, qualitative descriptive analysis

\section{PENDAHULUAN}

Jawa Barat menjadi salah satu
sentra produksi jagung. Diantara

beberapa wilayah yang merupakan sentra jagung yaitu Majalengka, Tasikmalaya, Sumedang dan Sukabumi. Salah satu 
sentra jagung yang saat ini sedang dikembangkan adalah Kabupaten Majalengka. Berdasarkan data dari BPS (2018) produksi jagung terbesar di Kabupaten Majalengka sebesar 151.646 Ton. Jagung menjadi komoditas unggulan di Kabupaten Majalengka karena kecocokan tanah dan iklim. Hal ini terbukti dari 4 kecamatan yang menjadi sentra produksi jagung yang produksi, luas panen dan produktivitas jagungnya terbesar seperti dapat dilihat pada Tabel 1 yaitu salah satunya Kecamatan Maja.

Tabel 1. Produksi, Luas Panen dan Produktivitas Jagung Per Kecamatan di Kabupaten Majalengka tahun 2018

\begin{tabular}{lccc}
\hline Kecamatan & $\begin{array}{c}\text { Produksi } \\
\text { (Ton) }\end{array}$ & $\begin{array}{c}\text { Luas } \\
\text { Panen } \\
(\mathrm{Ha})\end{array}$ & $\begin{array}{c}\text { Produkti- } \\
\text { vitas } \\
\text { (Ton/Ha) }\end{array}$ \\
\hline Majalengka & 27.072 & 3.366 & 8,04 \\
Bantarujeg & 27.000 & 3.533 & 7,64 \\
Maja & $\mathbf{2 1 . 2 8 5}$ & $\mathbf{2 . 7 3 3}$ & $\mathbf{7 , 7 8}$ \\
Cikijing & 14.297 & 1.873 & 7,63 \\
Argapura & 8.622 & 1.130 & 7,63 \\
\hline Sumber: Badan Pusat Statistik (2019)
\end{tabular}

Selama ini pertanian selalu dipahami sebagai bentuk kegiatan pengelolaan usahatani (on-farm) seperti perencanaan tanam teknis budidaya, pengolahan hasil, dan efisiensi penggunaan input untuk menghasilkan produk yang berkualitas dengan kuantitas yang cukup banyak yang pada umumnya dilakukan oleh produsen (petani). Padahal pertanian juga menyangkut kegiatan di luar usahatani (off-farm) sebagai proses komersialisasi hasil-hasil budidaya pertanian seperti pengolahan, pemasaran hasil pertanian dan lain sebagainya, dimana pelakunya pada umumnya adalah para pengepul, bandar, pedagang dan lainnya.

Namun, yang perlu menjadi perhatian adalah ketika memahami pertanian sebagai bisnis maka kedua komponen tersebut tidak akan terpisahkan dan membentuk satu kesatuan kegiatan usaha yang dimulai dari mata rantai produksi, pengolahan hingga pemasaran hasil. Perlunya pemahaman pertanian sebagai bentuk bisnis (biasa kita sebut sebagai agribisnis) maka kegiatan usaha pertanian dilakukan untuk memperoleh keuntungan. Pada hakekatnya agribisnis merupakan bisnis yang berbasis pada usaha pertanian mulai dari sektor hulu hingga hilir yang mengacu pada pandangan bahwa agribisnis bekerja pada rantai sektor pangan (food supply chain), sehingga dapat dikatakan bahwa agribisnis merupakan cara pandang ekonomi bagi usaha penyediaan pangan. Kegiatan usahatani bisa disebut agribisnis jika antar subsistem saling berkaitan. Dasar keterkaitan antar subsistem adalah adanya pihak yang menghubungkan seluruh subsistem dari hulu hingga hilir. 
Beberapa penelitian tentang subsistem agribisnis telah dilakukan pada berbagai macam komoditas. Kasimin (2013) meneliti agribisnis hortikultura yang bertujuan untuk menelaah beberapa kendala dalam pengembangan agribisnis serta menelaah keterkaitan pelaku dalam pengembangan agribisnis hortikultura unggulan di Aceh. Pentingnya melihat subsistem agribisnis dan menelaah keterkaitan antar subsistem di Kecamatan Maja adalah karena untuk mendukung usahatani yang lebih baik maka subsistem agribisnis juga harus baik juga. Penelitian ini ingin melihat bagaimana kondisi subsistem agribisnis jagung hibrida, melihat keterkaitan antar subsistem. Subsistem agribisnis meliputi pengadaan input, usahatani, pengolahan hasil pertanian, pemasaran dan lembaga penunjang.

\section{METODE PENELITIAN}

Penelitian ini dilaksanakan pada bulan Juli 2020 hingga September 2020 dengan mengambil lokasi di Desa Cihaur dan Desa Nunuk Baru, Kecamatan Maja, Kabupaten Majalengka. Penelitian ini menggunakan desain kualitatif. Metode penelitian yang digunakan dalam penelitian ini adalah deskriptif kualitatif yang bertujuan untuk menganalisis keterkaitan antar subsistem agribisnis jagung hibrida di Kecamatan Maja. Informasi untuk mendapatkan setiap subsistem agribisnis dengan melakukan wawancara dengan informan. Jumlah informan penelitian adalah sebanyak 24 orang pelaku agribisnis yaitu pemilik kios resmi, petani, kelompok tani, gabungan kelompok tani, industri pengolahan jagung, pedagang perantara, BPP, perbankan, dan Dinas Pertanian.

\section{HASIL DAN PEMBAHASAN}

\section{Sistem Agribisnis Jagung Hibrida}

Secara konseptual, agribisnis merupakan suatu sistem yang terdiri atas lima subsistem yang saling mendukung dan terkait satu sama lain yaitu subsistem pengadaan input, usahatani, pengolahan hasil pertanian, pemasaran dan lembaga penunjang. Berdasarkan hasil penelitian di Kecamatan Maja, keterkaitan subsistem agribisnis dengan usahatani komoditas jagung hibrida adalah sebagai berikut:

\section{Subsistem Pengadaan Input}

Pengadaan dan distribusi input merupakan sistem kegiatan industri dan perdagangan yang menghasilkan saprodi (sarana produksi) pertanian berupa pupuk, pestisida, alat mesin pertanian, dan benih (Rahim dan Astuti, 2005). 
Jumlah toko saprotan di Kecamatan Maja sudah mencukupi untuk petani membeli saprotan. Petani tidak kesulitan untuk membeli saprotan karena selain membeli, petani mendapatkan bantuan benih dan subsidi pupuk dari pemerintah. Tentunya hal tersebut menjadi kekuatan subsistem agribisnis karena petani dimudahkan dalam mencari dan memilih input produksi bagi usahatani jagung hibrida. Subsistem pengadaan input komoditas jagung hibrida Kecamatan Maja meliputi:

Benih; Menurut Rizal (2019), salah satu contoh benih bermutu yaitu benih hibrida. Jagung varietas hibrida dapat meningkatkan produktivitas hasil panen karena benih hibrida merupakan benih hasil perakitan dari kedua tetua yang mempunyai sifat genetik yang unggul. Namun varietas hibrida yang sama dengan lokasi yang berbeda belum tentu memiliki produktivitas yang sama. Hal tersebut dipengaruhi oleh keadaan iklim, cuaca, kondisi tanah, serta kandungan hara yang berbeda dan topografi yang berbeda, bisa juga keterampilan yang dimiliki oleh petani berbeda-beda. Berdasarkan wawancara pada tanggal 25 Agustus 2020 dengan pemilik toko saprotan yang bernama Rahmat (34 tahun), beliau mengatakan "Yang paling banyak dan memang cocok di daerah kita yaitu BISI 18 sama NK 212 itu rating paling tinggi dalam jumlah dus karena paling laku". Benih merk BISI 18 cocok ditanam di Desa Cihaur, sedangkan yang cocok ditanam di Desa Nunuk Baru adalah NK 212. Kedua benih tersebut paling banyak diminati karena benih merk tersebut kuat terhadap kekeringan, tahan hama dan penyakit, hasil panen jagung hibrida berat dan besar, cepat kering ketika dijemur, dan tahan busuk ketika musim hujan. Harga kedua benih tersebut sekitar Rp 80.000,-Selain membeli benih sendiri, petani Desa Cihaur dan Desa Nunuk Baru pernah mendapat bantuan benih dari pemerintah melalui kelompok tani. Hal ini menjadi bentuk kekuatan karena petani bisa mendapatkan input produksi dengan mudah.

$>\quad$ Pupuk; Unsur hara yang dibutuhkan jagung diantaranya nitrogen $(\mathrm{N})$, fosfor $(\mathrm{P})$, kalium (K). Nitrogen dibutuhkan tanaman jagung selama masa pertumbuhan sampai pematangan biji. Jumlah pupuk yang diperlukan sekitar 200-300 kg urea/ha. Selain itu, tanaman jagung juga membutuhkan pasokan unsur P sampai stadia lanjut, jumlah pupuk fosfat yang dianjurkan sekitar $40-80 \mathrm{~kg}$ TSP/ha yang diberikan sebagai pupuk dasar, sedangkan dosis pupuk K kurang 
lebih $50 \mathrm{~kg}$ KCI per hektar, diberikan pada waktu tanam sebagai pupuk dasar. Pupuk diberikan di dalam lubang di kiri atau di kanan lubang tanam dengan jarak $7 \mathrm{~cm}$ dan kedalaman $10 \mathrm{~cm}$ (Suprapto, 1995). Pupuk organik yang dipakai adalah petroganik yang komposisinya adalah kotoran ayam dan sekam. Unsur hara yang dibutuhkan jagung diantaranya nitrogen $(\mathrm{N})$, fosfor $(\mathrm{P})$, kalium $(\mathrm{K})$. Pupuk yang harus tersedia di kios resmi dan petani harus menggunakan pupuk itu untuk usahataninya adalah pupuk anorganik. Karena jika tidak menggunakan pupuk anorganik, tanaman jagung hibrida tidak bisa "Pupuk anorganik yang dipakai adalah urea, $\mathrm{KCl}$, phonska, SP-36 dengan harga urea $R p \quad 90.000 /$ karung, $\quad S P-36 \quad R p$ 100.000/karung, phonska $\quad R p$ 115.000/karung, dan $\mathrm{KCl} \quad \mathrm{Rp}$ 350.000/karung." (Rahmat, 34 tahun)

$>$ Obat-obatan; Berdasarkan informasi di lapangan yaitu wawancara dengan pemilik kios resmi Mitra Tani yang bernama Tarpin (32 tahun), beliau berkata " Obat-obatan yang ada di toko saprotan untuk membasmi hama dan penyakit jagung hibrida adalah Ridomil, Fastac, Gramoxon, Gempur, dan Calaris. Harga Fastac Rp 100.000,- sedangkan harga Ridomil dan Calaris Rp 150.000,- per liter. Gramoxon dan Gempur bisa dibeli petani seharga $R p$ 60.000,-Banyak petani bilang harga obat-obatan tersebut cukup mahal". Hal tersebut menjadi sebuah ancaman karena selain mahal, dari pemerintah juga belum ada bantuan berupa obat-obatan.

$>$ Tenaga Kerja; Tenaga kerja memiliki peranan yang sangat penting dalam menjamin keberlanjutan usahatani. Tenaga kerja usahatani jagung hibrida Desa Cihaur dan Desa Nunuk Baru terdiri atas tenaga kerja keluarga dan bukan keluarga dengan upah di Desa Cihaur untuk perempuan Rp 40.000,- dan lakilaki Rp 50.000,-. Upah tenaga kerja Desa Nunuk Baru untuk perempuan sebesar Rp 50.000,- dan laki-laki Rp 60.000,-.

\section{Subsistem Usahatani}

Usahatani merupakan sistem kegiatan yang menggunakan saprotan untuk menghasilkan komoditas pertanian. Di Indonesia, tanaman jagung tumbuh dan berproduksi optimum di dataran rendah sampai ketinggian $750 \mathrm{mdpl}$. Di Pulau Jawa dan Madura sekitar 90\% dari 4 luasan penanaman jagung terletak di bawah ketinggian $750 \mathrm{mdpl}$. Suhu udara yang ideal untuk perkecambahan benih adalah $30 \circ \mathrm{C}-32 \mathrm{oC}$ dengan kapasitas air tanah antara 25\% - 60\%. Keadaan suhu 
rendah dan tanah basah sering menyebabkan benih jagung membusuk (Purwono dan Hartono 2007). Subsistem usahatani komoditas jagung hibrida Kecamatan Maja meliputi:

Lahan; Sebelum memulai budidaya jagung hibrida perlu lahan yang mendukung budidaya tersebut. Sebagian besar budidaya jagung hibrida di Desa Cihaur maupun Desa Nunuk Baru dilakukan di lahan sendiri. Namun, ada juga lahan bengkok atau lahan garapan milik desa. Rata-rata luas lahan di Desa Cihaur sebesar 0,77 ha dan di Desa Nunuk Baru sebesar 0,86 ha.

Budidaya; Pada saat melakukan wawancara tanggal 24 Agustus 2020, petani bernama Wahyu berkata "Nanam jagung mudah kan pengolahan lahan cuma sekali dan efektif karena kecocokan tanah dan ketinggian daerah". Budidaya jagung hibrida tidak memerlukan perawatan intensif. Kemudahan berbudidaya jagung hibrida menjadi kekuatan petani untuk berusahatani. Petani menjual hasil panen jagung hibrida ke bandar atau langsung ke pabrik pengolah jagung hibrida. Hal tersebut menjadi kekuatan karena bahan baku untuk mengolah jagung mudah ditemukan.
Biaya produksi jagung hibrida di Desa Cihaur sebesar Rp. 3.686.567,97 dan di Desa Nunuk Baru sebesar Rp. 6.927.642,25.

Berdasarkan penelitian Saidah, et al (2020) dapat disimpulkan seluruh bagian jagung bisa dimanfaatkan. Bahkan limbah tanaman jagung juga dapat dimanfaatkan diantaranya tebon jagung, jerami jagung, kulit buah jagung, tongkol jagung, tumpi jagung, dan biji jagung.

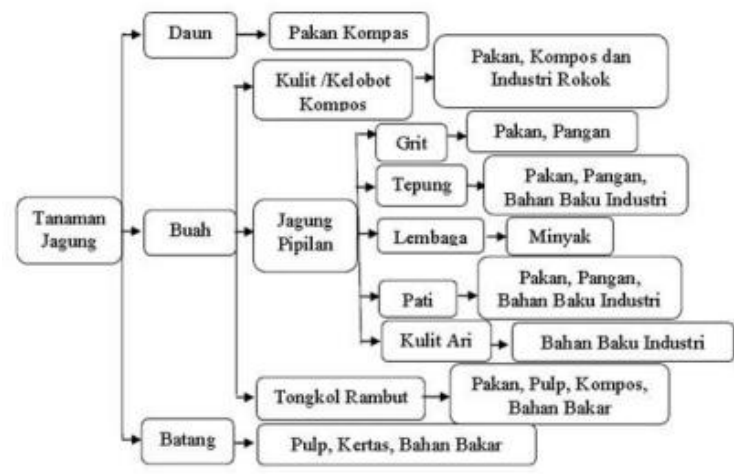

Gambar 1. Pohon Industri Jagung (Tarliah et al, 2017)

Petani memilih menanam jagung hibrida karena hampir seluruh bagian jagung bisa diolah dan memiliki nilai ekonomis bisa dilihat dari pohon industri jagung yang dikemukakan oleh Tarliah et al (2017).

Walaupun jagung hibrida memiliki potensi namun penanaman jagung hibrida terfokus di daerah tertentu dan menjadi sebuah kelemahan. Data luas tanam jagung hibrida di desa Kecamatan Maja ditunjukkan pada Gambar 2. 


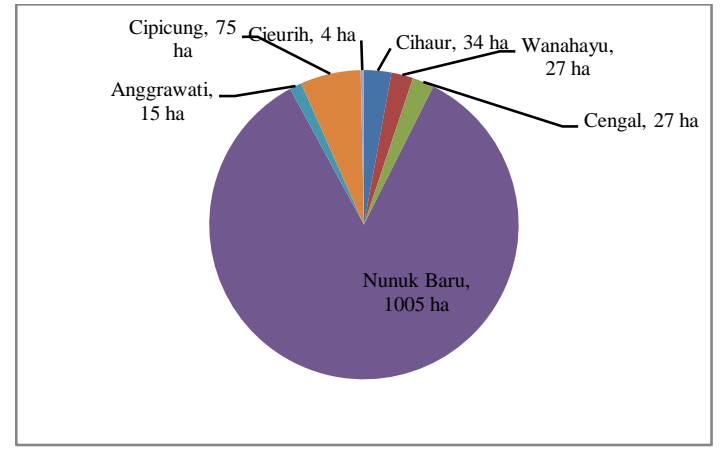

Gambar 2. Data Luas Tanam Jagung Hibrida Per Desa Kecamatan Maja tahun 2020 (BPP Kecamatan Maja)

Dukungan kelompok tani terhadap usahatani jagung sangat baik sehingga menjadikan kekuatan untuk usahatani jagung hibrida. Kelompok tani sering mendapatkan penyuluhan dari BPP. Dengan adanya pertemuan kelompok tani dengan BPP, maka petani banyak mendapatkan bantuan dan menjadikan petani makmur serta sejahtera. Dengan adanya pembagian tugas diantara para anggota kelompok tani jagung maka kelompok tani berfungsi sebagaimana semestinya. Jumlah gapoktan di Kecamatan Maja sebanyak 18 dengan kelompok tani sebanyak 105 yang tersebar di seluruh desa.

Pasca panen; Biji jagung hibrida dengan klobot yang tidak tertutup sempurna merupakan peluang pertama infeksi jamur, khususnya apabila biji yang tidak menutup ini terserang hama. Proses pengeringan yang dilakukan pada tempat yang kebersihannya tidak terjaga dengan baik dan tidak diaturnya kondisi ruangan penyimpanan yang tepat dapat meningkatkan kadar air jagung dan menyebabkan jamur tumbuh dengan subur dan menghasilkan aflatoksin (Rahayu, et al, 2003). Berdasarkan wawancara dengan penyuluh bernama Pak Loyn, beliau berkata "Petani ataupun bandar belum bisa memasok jagung pipilan kering standar pabrik yaitu dengan kadar air 14\%. Sedangkan petani maupun bandar tidak memiliki mesin pengering (dryer) karena harga yang mahal. Petani hanya bisa mengeringkan jagung pada kadar air 16\%. Selain itu, ketika jagung hibrida diserang oleh aflatoksin maka tidak dapat masuk ke industri pakan dan dijual untuk pakan itik yang harganya sangat rendah."

\section{Subsistem Pengolahan Hasil}

Kebutuhan jagung untuk industri pakan tiap tahun terus meningkat secara signifikan sejalan dengan pesatnya perkembangan industri peternakan (Rachman, 2003). Hal tersebut menjadi sebuah peluang untuk mengembangkan usaha olahan jagung.

Hasil penelitian Swastika et al (2011) mengenai analisis sinkronisasi menunjukkan bahwa 7 dari 10 provinsi 
sentra produksi jagung adalah juga sentra konsumsi jagung untuk pabrik pakan. Ini berarti bahwa penempatan pabrik pakan sudah hampir sinkron dengan sentra produksi jagung. Tiga provinsi yang bukan merupakan sentra produksi jagung dapat memperoleh jagung dari provinsi terdekat yang produksi jagungnya surplus. Kecamatan Maja belum memiliki pabrik pengolahan jagung untuk pakan maupun home industry pengolah jagung, padahal Majalengka menjadi salah satu sentra produksi jagung tertinggi. Produksi jagung hibrida di Kecamatan Maja pada tahun 2019 sebesar 21.285 ton/ha. Artinya harusnya didukung dengan terdapat pengolahan industri di Kecamatan Maja. Hal tersebut menjadi kelemahan dari subsistem pengolahan hasil pertanian dan harusnya menjadi perhatian pemerintah. Hal itu terjadi karena mental petani belum terbuka untuk mengolah jagung, belum mau mencoba dan belum tersosialisasi dengan baik. Kecamatan Maja juga belum ada yang menginvestasikan untuk membangun pabrik pengolahan jagung. Selain itu, dari pemerintah belum ada bantuan untuk industri pakan. Namun, Desa Cihaur Dusun Pasawahan memiliki peternakan bernama Lestari Farm. Lestari Farm sudah sangat terkenal bahkan banyak mahasiswa dari universitas lain melakukan penelitian di sana. Lestari Farm mengolah jagung untuk pakan ayam di peternakan mereka sendiri, namun sebagian ada yang dijual. Alat yang digunakan untuk mengolah jagung adalah mixer dan alat pemecah jagung, sedangkan bahan yang digunakan adalah konsentrat dan biji jagung. Tongkol jagung digunakan untuk makanan sapi, namun di Lestari Farm tidak digunakan dan diberikan kepada peternak yang membutuhkan. Berdasarkan wawancara dengan Pa Eman pemilik Lestari Farm, beliau mengatakan "Produksi pakan jagung skala kecil mudah dilakukan tapi kalau skala besar sulit karena harus punya alat yang mahal”. Hal tersebut menjadi kekuatan untuk individu yang ingin mengolah jagung hibrida.

\section{Subsistem Pemasaran}

Pada wawancara tanggal 23 Agustus 2020 bersama bandar jagung hibrida, beliau mengatakan "Mengumpulkan jagung dari manamana. Dari Kecamatan Argapura, Cikijing, Bantarujeg, Lemahsugih, Kota Garut, Ciamis, Tegal dan Gorontalo”. Hal tersebut terjadi karena pasokan jagung hibrida di Kecamatan Maja tidak dapat memenuhi kebutuhan dan menjadi 
sebuah ancaman, karena membutuhkan biaya transportasi yang lebih tinggi dibandingkan dengan mengambil jagung dari dalam daerah. Jika terjadi kelebihan ketersediaan jagung hibrida dikirim ke Brebes. Kebutuhan jagung untuk pakan cukup tinggi sehingga pakan unggas juga dipasarkan sampai ke Garut, Ciamis, Tasikmalaya, dll. Hal tersebut menjadi bentuk peluang untuk pemasaran jagung hibrida ke seluruh Indonesia. Harga jual ditentukan oleh bandar sebesar kisaran Rp3.200,00. Karena mudah berbudidaya jagung hibrida, petani memilih untuk menanam jagung hibrida. Hal ini menjadi kekuatan karena meningkatnya produksi yang diakibatkan oleh penggunaan benih jagung hibrida akan mengakibatkan peningkatan pendapatan (Antara, 2012).

Tidak terdapat koperasi di Kecamatan Maja karena koperasi tidak berjalan dengan baik, namun kelompok tani membantu anggotanya untuk pemasaran jagung hibrida. BPP juga membantu kelompok tani untuk memasarkan jagung hibrida ke konsumen.

\section{Subsistem Lembaga Penunjang}

Usahatani merupakan suatu kegiatan bercocok tanam yang tidak dapat dilakukan secara mandiri oleh petani melainkan membutuhkan bantuan pihak lain sebagai pendukung usahanya yaitu lembaga penunjang. Lembaga penunjang terdiri atas financial industry (perbankan), infrastruktur (prasarana dan sarana), research and development, human resources dan human natural, pendidikan dan konsultan penyuluhan pertanian, layanan informasi agribisnis, dan kebijakan pemerintah (Rahim dan Hastuti, 2005). Lembaga penunjang di Kecamatan Maja adalah meliputi;

BPP; Pemerintah melakukan pelatihan khusus untuk petani melalui BPP. Lalu BPP melakukan penyuluhan ke petani. Petani sangat antusias mengikuti penyuluhan. Hal tersebut adalah bentuk kekuatan agar petani selalu terhubung dengan BPP dan pemerintah. Metode penyuluhan yang digunakan adalah pemaparan materi disesuaikan dengan kebutuhan petani. Penyuluhan diawali dengan mengidentifikasi masalah petani lalu mencari solusi untuk memecahkan masalah tersebut. Tugas BPP selain untuk memberikan info penyuluhan adalah pembinaan kepada pelaku agribisnis, asosiasi, mengenalkan pengusaha dengan petani, membantu pemasaran dan sebagainya. BPP membantu petani dari awal input hingga output budidaya jagung. Masalah 
penyuluhan di Kecamatan Maja adalah perbedaan pemikiran antara BPP dengan petani sehingga materi yang disampaikan saat penyuluhan tidak selalu dipraktikkan di lapangan. Hal tersebut menjadi bentuk kelemahan karena petani belum mau mencoba hal baru.

\section{$>\quad$ Pemerintah; Pemerintah}

memberikan program peningkatan produktivitas mutu hasil tanaman berupa bantuan benih jagung hibrida. Hal tersebut menjadi bentuk peluang untuk pengembangan usahatani dan pengembangan agribisnis, karena pemerintah memberikan kultivator dan alat pemipil jagung untuk pengolahan jagung hibrida menjadi tepung jagung. Berdasarkan wawancara bersama Kasie Palawija Dinas Pertanian yaitu Ibu Ratih, beliau berkata "Majalengka diberikan bantuan benih umum 3 karena produktivitas jagung hibrida di Majalengka sudah diatas produktivitas provinsi yaitu sekitar 7,4 ton/ha. Varietas benih uтum 3 yaitu BISI 226, BISI 228, NASA dan RK. Bantuan tersebut tersebar ke seluruh kecamatan yang mengajukan bantuan tersebut. Petani sebenarnya menginginkan benih umum 2 seperti NK, pioneer, BISI karena benih tersebut lebih bagus daripada benih uтum 3. Perbedaan produktivitas umum 2 dan uтит 3 sampai $30 \%$ menyebabkan pendapatan petani menurun. Penurunan tersebut bukan disebabkan oleh perilaku petani dalam berusahatani jagung, melainkan dari jenis benih yang diberikan".

$>$ Perbankan; Petani merasa kesulitan untuk mengakses permodalan. Hal tersebut menjadi sebuah ancaman, karena petani akan kesusahan untuk memulai budidaya jagung hibrida. Berdasarkan informasi di lapangan, tidak terdapat koperasi simpan pinjam akhirnya petani hanya bisa meminjam ke bandar atau perbankan. Warga Desa Cihaur jika ingin mengajukan pinjaman harus ke BRI Argapura. Warga Desa Nunuk Baru jika ingin mengajukan pinjaman bisa ke BRI Maja. Jarak yang jauh menjadi salah satu alasan petani belum mau mengakses modal ke BRI. Bentuk nyata untuk Kecamatan Maja yang sudah dilakukan oleh BRI menurut subsistemnya adalah peminjaman untuk ternak ayam petelor, budidaya bawang daun dan bawang merah, pemasaran jagung, pembenihan jagung dan obat obatan jagung. Peminjaman hanya dilakukan oleh individual dan belum ada keterkaitan dari pihak bank dengan kelompok tani. Alasan kelompok tani tidak mengajukan pinjaman adalah karena takut jika terjadi 
gagal panen. Berdasarkan wawancara dengan Pak Heri Kepala Unit BRI Maja, beliau berkata "Ketua kelompok tani seharusnya bisa mengatasi hal tersebut karena ketua kelompok tani pasti mengetahui lahan dan kebutuhan anggotanya". Program yang ditawarkan BRI untuk petani jagung di Desa Cihaur adalah pinjaman untuk pemasaran atau jual beli jagung. Tidak adanya komitmen atau peran nyata BRI untuk membangun agribisnis di pedesaan menjadi sebuah ancaman ditambah para peminjam tidak ada yang meminjam ke BRI untuk mengolah jagung hibrida. Para bandar atau petani bisa menjualbelikan jagungnya dengan pinjaman modal dari BRI setiap bulannya. Hal tersebut menjadi sebuah peluang untuk petani memulai usahatani jagung namun harus ada kemauan dari petani untuk memenuhi persyaratan peminjaman.

\section{Keterkaitan Antar Subsistem} Agribisnis Jagung Hibrida Kecamatan

\section{Maja}

Menurut Matakena (2017), Harapan dengan adanya agribisnis maka paradigma baru dalam rangka pembangunan ekonomi yang berbasis pertanian dapat dicapai dengan melibatkan subsistem-subsistem agribisnis secara simultan dan terintegrasi mulai dari hulu hingga hilir. Dengan demikian, agribisnis akan berkembang dengan baik apabila tidak ada hambatan yang menghalangi salah satu subsistem yang ada.

Keterkaitan antar subsistem memerlukan adanya pelaku yang mengelola antar subsistem. Pelaku yang mengelola antar subsistem agribisnis adalah BPP. BPP mengelola seluruh subsistem dari mulai hulu hingga hilir, namun tidak pada subsistem pengolahan hasil pertanian karena industri pengolah jagung di Kecamatan Maja hanya Lestari Farm dan BPP tidak menghubungkan pelaku agribisnis dengan Lestari Farm. Pengolahan jagung hibrida di Kecamatan Maja hanya untuk konsumsi pakan pribadi dan tidak untuk dijual. Bandar jagung hibrida hanya memasok jagung ke ternak ayam petelor dan belum pernah memasok ke pabrik pakan. Alasannya yang pertama adalah petani ataupun bandar belum bisa memasok jagung pipilan kering standar pabrik yaitu dengan kadar air 14\%. Sedangkan petani maupun bandar tidak memiliki mesin pengering (dryer) karena harga yang mahal. Petani hanya bisa mengeringkan jagung pada kadar air 16\%. Selain itu, ketika jagung hibrida diserang oleh 
aflatoksin maka tidak dapat masuk ke industri pakan dan dijual untuk pakan itik yang harganya sangat rendah. BPP harus memberikan penyuluhan tentang penanganan pascapanen agar tidak merugikan petani. Alasan yang kedua adalah pada pembiayaan. Pembayaran dari pabrik untuk petani atau bandar membutuhkan waktu yang sangat lama, padahal jagung hibrida sudah diberikan ke pihak pabrik. Alasan yang ketiga adalah kesulitan untuk keberlanjutan pasokan dari petani untuk pabrik. Ketersediaan jagung di Kecamatan Maja tidak selalu terpenuhi karena petani lebih banyak menanam di tegalan dan hanya pada musim hujan. Penanaman jagung hibrida tidak terpola dan tidak mengikuti informasi pasar, padahal seharusnya pasokan jagung hibrida harus stabil setiap bulan mengingat penanaman jagung hingga pemasaran membutuhkan waktu yang lama sekitar 4 bulan. Pada Januari tahun 2021, BPP akan mencoba kemitraan dengan PT. Japfa Comfeed Indonesia dengan memasok bahan baku berupa jagung hibrida pipilan kering untuk dijadikan pakan hewan ternak. Hal tersebut menjadi peluang agar petani dan bandar bisa memasok jagung hibrida. Jarak yang dekat antara Majalengka dan PT. Japfa Comfeed Indonesia memudahkan BPP dan pihak pabrik untuk terus terhubung dalam pemasokan bahan baku jagung hibrida. BPP membantu petani dalam bantuan benih dan subsidi pupuk untuk petani. Dalam usahatani jagung hibrida, BPP membantu permasalahan usahatani petani pada saat penyuluhan. Pemasaran jagung juga melibatkan BPP di dalamnya. BPP mengawasi dan menekankan agar harga tidak memberatkan petani.

\section{KESIMPULAN DAN SARAN}

\section{Kesimpulan}

Penerapan agribisnis pada usahatani jagung di Kecamatan Maja belum terkait antar subsistem karena tidak adanya keterkaitan pada subsistem pengolahan hasil pertanian dengan subsistem lainnya. Meskipun ada 1 industri pengolahan jagung, namun BPP tidak menghubungkan pelaku agribisnis dengan industri pengolahan.

\section{Saran}

Terdapat subsistem agribisnis dan keberadaanya masih bersifat parsial. Sehingga diperlukan pihak yang mengelola subsistem agribisnis dari hulu hingga hilir sehingga antar subsistem saling terkait. Dengan adanya koperasi, petani dan pihak lainnya bisa lebih 
mudah mengakses permodalan dan membantu pemasaran jagung hibrida. Di Kecamatan Maja tidak ada koperasi, pemerintah harusnya mempertimbangkan tersedianya koperasi unit desa membuat petani lebih sejahtera. Dengan adanya program pengembangan jagung untuk pemenuhan industri dan mengurangi impor membuat usahatani jagung hibrida menjadi lebih baik lagi. Program pemenuhan industri dengan bantuan berupa mesin pengeringan jagung mengingat petani kesulitan untuk mengeringkan jagung dengan kadar air $14 \%$ yang diminta oleh pabrik pakan. Petani hanya bisa mengeringkan jagung dengan kadar air 16\% menggunakan panas matahari.

\section{DAFTAR PUSTAKA}

Antara, M., (2012). Analisis Produksi dan Komparatif antara Usahatani Jagung Hibrida dengan Nonhibrida di Kecamatan Palolo Kabupaten Sigi. Agroland: Jurnal Ilmu-ilmu Pertanian, 17(1).

Badan Pusat Statistik. (2019). Kabupaten Majalengka dalam angka tahun 2019. BPS.

Badan Pusat Statistik. (2018). Kecamatan Maja Kabupaten Majalengka dalam angka tahun 2018. BPS.

Badan Pusat Statistik. (2017). Kabupaten Majalengka Dalam Angka tahun 2017. BPS. Kabupaten Majalengka.

Badan Pusat Statistik. (2017). Produksi Jagung Menurut Provinsi, 20142018. BPS.
Badan Pusat Statistik. (2017). Luas Panen Jagung Menurut Provinsi, 2014-2018. BPS.

Kasimin, S. (2013). Keterkaitan produk dan pelaku dalam pengembangan agribisnis hortikultura unggulan di Provinsi Aceh. Jurnal Manajemen \& Agribisnis, 10(2), 117-127.

Matakena, S. (2017). Agribisnis Komoditi Jeruk Manis (Citrus Sinensis L) di Kampung Wadio Distrik Nabire Barat Kabupaten Nabire. Jurnal Fapertanak: Jurnal Pertanian dan Peternakan, 2(2), 35-48.

Purwono, H. R., \& Hartono, R. (2007). Bertanam Jagung Unggul. Jakarta (ID): Penebar Swadaya.

Rachman, B. (2003). Perdagangan nternasional Komoditas Jagung Ekonomi Jagung Indonesia. Badan 'Litbang Pertanian. Jakarta.

Rahayu, E. S., Raharjo, S., \& Rahmianna, A. A. (2003). Cemaran aflatoksin pada produksi jagung di daerah Jawa Timur=(aflatoxin contamination during corn production in East Java). Agritech, 23(2003).

Rahim, A., dan D.R.D.Hastuti, (2005), Sistem Manajemen Agribisnis, Universitas Negeri Makassar. Makassar

RIZAL, Y. (2019). Strategi Pengembangan Usahatani Jagung Hibrida. (Doctoral dissertation, Universitas Siliwangi).

Saidah, Z., Andriani, R dan Rachmawati, E. (2020). Kajian Peluang Usahatani Jagung di Kabupaten Majalengka Dalam Mendukung Industri Pakan Ternak. Prosiding Konser Karya Ilmiah Nasional

Swastika, D. K., Agustian, A., \& Sudaryanto, T. (2011). Analisis senjang penawaran dan permintaan jagung pakan dengan pendekatan sinkronisasi sentra produksi, pabrik 
pakan, dan populasi ternak di Indonesia. Inform Pertan, 20(2), 65-75.
Tarliah, T. and Kurniasih, D. ( 2017). Kompetensi Inti Industri Daerah Kabupaten Majalengka. 